\title{
Carcinoembryonic Antigen-Related Cell Adhesion Molecule 7
}

National Cancer Institute

\section{Source}

National Cancer Institute. Carcinoembryonic Antigen-Related Cell Adhesion Molecule 7. NCl Thesaurus. Code C25903.

Carcinoembryonic antigen-related cell adhesion molecule 7 (265 aa, $29 \mathrm{kDa}$ ) is encoded by the human CEACAM7 gene. This protein may play a role in tumor suppresssion. 